The Cryosphere Discuss., doi:10.5194/tc-2016-141, 2016

Manuscript under review for journal The Cryosphere

Published: 15 July 2016

(c) Author(s) 2016. CC-BY 3.0 License.

\title{
Possible groundwater dominance in the subglacial hydrology of ice sheet interiors: example at Dome C, East Antarctica
}

\author{
Brad T. Gooch ${ }^{1}$, Sasha P. Carter ${ }^{2}$, Omar Ghattas ${ }^{3}$, Duncan A. Young ${ }^{1}$, and Donald D. Blankenship ${ }^{1}$ \\ ${ }^{1}$ Institute for Geophysics, Jackson School of Geosciences, University of Texas, Austin, 78758, USA \\ $5{ }^{2}$ Institute of Geophysics and Planetary Physics, Scripps Institution of Oceanography, University of California, San Diego, \\ 92037, USA \\ ${ }^{3}$ Institute for Computational Engineering \& Sciences, University of Texas, Austin, 78712, USA \\ Correspondence to: Brad T. Gooch (bgooch@utexas.edu)
}

\begin{abstract}
We hypothesize that groundwater systems may be the main water transport mechanism over (distributed,
10 inefficient) water sheets at large scales in the interiors of ice sheets where melt rates are very low. We compare melt rate magnitudes to potential groundwater volume fluxes and also calculate the theoretical transmissivity ranges of subglacial water sheet and groundwater flow systems. Theoretical groundwater systems are on par with or are more transmissive than water sheets for the upper half of the permeability spectrum. In addition, we develop a $2 \mathrm{D}$ cross-sectional subglacial flow path model that connects subglacial lakes near Dome C, East Antarctica. This model integrates subglacial water sheet flux

15 and hypothetical groundwater flow forcing, better bridging two historically disparate modeling frameworks - subglacial hydrology and ice sheet hydrogeology. Our model results suggest that the water sheet thickness can be highly dependent on groundwater flux and that the water sheet transmissivity is within the total range of the modeled groundwater system transmissivity. We infer from these results that subglacial lake stability and basal radar reflections underneath the interior of East Antarctica may possibly be affected by groundwater flow.
\end{abstract}

\section{Observations and Background Information}

While much study (e.g. Weertman, 1966; Shreve, 1972; for review, see Flowers, 2015) has been given to the ways in which basal meltwater transports under faster flowing ice bodies (i.e. mountain glaciers and ice streams), relatively much less has been done to show how meltwater transports under the interiors of continental ice sheets like the East Antarctic Ice Sheet (e.g. Carter et al., 2009a; Wright et al., 2012, 2014). Subglacial melt rates under the vast majority of the interiors of 25 these kinds of ice sheets are estimated to be very low compared to the higher melting zones underneath ice streams $(<10 \mathrm{~mm}$ $\mathrm{yr}^{-1}$; Pattyn, 2010). Some (e.g. Creyts and Schoof, 2009) have modeled the transport of subglacial meltwater via water sheets sitting at the ice/bed interface while others (e.g. Boulton and Jones, 1979) have used groundwater flow through the porous sediment or bedrock. While porous groundwater flow is not capable of transporting the bulk of the meltwater underneath fast flowing ice (i.e. high melt rates in ice streams and outlet glaciers; Alley, 1989), those areas are a small

30 fraction of the total area underneath the interiors of ice sheets like that present in East Antarctica. Groundwater systems 
The Cryosphere Discuss., doi:10.5194/tc-2016-141, 2016

Manuscript under review for journal The Cryosphere

Published: 15 July 2016

(c) Author(s) 2016. CC-BY 3.0 License.

could still be important in considering the large-scale transport of meltwater for much of the ice sheet interior (outside of ice stream and outlet glacier areas; cf. lake locations presented in Smith et al., 2009) and useful to consider in future continental ice sheet models. Ice sheets have also been shown to affect regional-to-continental scale groundwater flow systems, which is a closely related field of active research (e.g. Boulton et al., 1995; Piotrowski, 1997; Person et al., 2007a; Lemieux et al., 35 2008).

The presence of large and small subglacial lakes underneath the East Antarctic Ice Sheet (and West Antarctic) is now well established (Siegert et al., 2005a; Smith et al., 2009; Wright and Siegert, 2014). Originally, subglacial lakes were thought of as long-lasting stable environments whose behavior impacted only the overlying ice and received their water

40 entirely from local sources (Tikku et al., 2005). More recently, it has been shown that not only are subglacial lakes capable of releasing many cubic kilometers of water in a period of about a year (Fricker et al., 2007), but that these periodic releases can significantly impact the flow of ice downstream (Stearns et al., 2008; Fricker, 2008). Lake activity has been modeled as driven by thermodynamic and deformation processes concentrated at the ice/bed interface (Carter et al., 2009b, 2015) processes that will be less important in a groundwater-driven system. The observed filling rates for many of the lakes now

45 known to underlie most of the fast-flowing ice streams appear to require meltwater input from the entire subglacial hydraulic catchment (Anandakrishnan and Alley, 1997; Smith et al., 2009; Carter et al., 2011), meaning that hydraulic processes in the uppermost part of the hydraulic catchment influence the quantity, chemistry, and biology of water much further downstream. Consequently, a complete understanding of the subglacial hydraulic system begins with an examination of its headwaters.

Although much attention has recently focused on "active lakes" in fast flowing ice streams and outlet glaciers, the first lakes discovered in Antarctica were found close to the ice divides (i.e. slower-moving ice) using radio-echo sounding (also known as ice-penetrating radar). The criterion used to identify lakes with radio-echo sounding ("radar lakes") is a hydraulically flat, bright reflection of consistent reflectivity that is brighter than its surroundings (Siegert et al., 2005a; Smith et al., 2009; Carter et al., 2007; Wright and Siegert, 2012). When this same criterion is applied to radio-echo sounding data

55 from "active lakes" (with the exception of Subglacial Lake Mercer; Carter et al., 2007; Fricker and Scambos, 2009; Fricker et al., 2007, 2010) it often fails at least one if not multiple tests for detecting "radar lakes" such as hydraulic flatness, specularity, and brightness relative to its surroundings (e.g. Smith et al., 2009; Christianson et al., 2012; Siegert et al., 2014; Wright et al., 2014). Conversely, satellite and GPS data collected over most "radar lakes" (with the exception of the Adventure Trench lakes of Wingham et al. (2006) show no detectable change. Towards understanding these observations,

60 Carter et al. (2015) investigated drainage mechanisms necessary to sustain "active lakes" and argued that they would likely exist in areas that befoul traditional radar detection methods due to the lakes being surrounded by saturated sediments that impair the radar reflection contrast. In this work, we explore drainage mechanisms for "radar lakes" that may explain why they do not typically exhibit detectable vertical surface motion. 
The Cryosphere Discuss., doi:10.5194/tc-2016-141, 2016

Manuscript under review for journal The Cryosphere

Published: 15 July 2016

(c) Author(s) 2016. CC-BY 3.0 License.

\section{Hypotheses}

We hypothesize that groundwater systems may have a significant role in the subglacial hydrological systems proximal to ice divides (and perhaps much of the areas with low melt rates) underneath continental ice sheets such as the East Antarctic Ice Sheet. This is due to the low production of meltwater, usually less than $10 \mathrm{~mm} \mathrm{yr}^{-1}$, underneath areas of very low basal shear stress (i.e. low frictional heating from slow moving ice). These behaviors are demonstrated in Fig. 1 where we compare a range of melt rates at the base of a hypothetical ice sheet that is similar to basal conditions in the

70 interior of East Antarctica close to an ice divide (see Fig. S1 for the specific area used) to the volume flux of groundwater (cf. fluid velocity; for definition specifics, see Stauffer, 2006) across the majority of hydrogeologic values (see Table 8.2 of Singhal and Gupta, 2010), given interior East Antarctic pressure potentials. The groundwater volume flux, $q\left(\mathrm{~mm} \mathrm{yr}^{-1}\right)$, is equal to $-k \nabla P / \mu$ where $k$ is the permeability $\left(\mathrm{m}^{2}\right)$ of the porous medium, $\mu$ is the dynamic viscosity of the water $\left(8.94 \times 10^{-4}\right.$ $\mathrm{Pa} \mathrm{s}$ ), and $\nabla P$ is the gradient of the pore water pressure $\left(\mathrm{Pa} \mathrm{m}^{-1}\right)$. Permeability (units typically in $\mathrm{L}^{2}$ or darcy) is a measure of

75 the ability of a porous media to transmit a fluid such as water; it ranges over thirteen orders of magnitude for geologic materials (unconsolidated sediments and porous sedimentary rocks have much higher values than highly consolidated or crystalline unfractured rocks). Figure 1 shows that groundwater volume flux values are on par with melt rate magnitudes (1$\left.100 \mathrm{~mm} \mathrm{yr}^{-1}\right)$ at high-to-moderate permeability for low-pressure gradients and from moderate-to-low permeability at higherpressure gradients. This means that for roughly half of the hydrogeologic permeability spectrum meltwater can be

80 transported as groundwater.

This hypothesis is further supported by calculations of the transmissivity of groundwater systems compared to a subglacial water sheet (or films; a lá Weertman, 1966), which is still the de facto model for continental scale subglacial water transport (Johnson, 2002; Johnson and Fastook, 2002; Le Brocq et al., 2009). Transmissivity is a measure of a water system

85 to carry water laterally and is equal to the product of the hydraulic conductivity of the water system and the thickness of that system (i.e. $T=K b$, where $K$ is the hydraulic conductivity and $b$ is the thickness of the water-saturated layer). Hydraulic conductivity is a measure of the ease with which fluid moves through a porous or fractured media and is related to permeability by the relation $K=k \rho g / \mu$ where $\rho$ is the density of the fluid and $g$ is acceleration due to Earth's gravity. Figure 2 shows the transmissivity of the hydraulic conductivity end members of the groundwater and water sheet systems

90 (see Appendix A for the specific mathematical details). These comparisons also demonstrate that more water can be transmitted via groundwater than via water sheet systems for roughly half of the hydrogeologic permeability spectrum.

We also hypothesize that given the potential in subglacial water transport via groundwater that subglacial lakes may be fairly stable through the ability of the bed substrate to diffuse excess water away without giving an ice surface expression.

95 This effect could explain why so many of the "radar lakes" in the interior of East Antarctica are not observable from ice surface elevation changes (cf. "active lakes"). Finally, we hypothesize that the ice sheet corrected basal radar return signal 
The Cryosphere Discuss., doi:10.5194/tc-2016-141, 2016

Manuscript under review for journal The Cryosphere

Published: 15 July 2016

(c) Author(s) 2016. CC-BY 3.0 License.

known as the basal reflection coefficient, assuming to be dominantly a function of the water content as the base of the ice sheet (Peters et al., 2007), could be directly resultant from the hydrogeologic properties of the bed. This would mean that a groundwater system present at the ice sheet bed could alter the signal of the radar return by modulating the basal water sheet thickness. We leave this third hypothesis untested here as it is out of the scope of this work.

\section{$3 \quad$ Numerical Modeling Methods}

To further test these hypotheses we developed a novel 1D subglacial interface water sheet model (applicable here due to the large length scale) coupled to a $2 \mathrm{D}$ groundwater model applied to the study area of Dome $\mathrm{C}$ in East Antarctica (see Fig. 3). This coupled model simulates a cross-sectional model domain (along a subglacial flow path) where the water sheet thickness is solved along the top boundary (i.e. ice base) of the cross-sectional groundwater domain. The water sheet is solved in a curvilinear one-dimensional sense as its thickness is much less than the simulated aquifer thickness. The objective of our model was to utilize groundwater volume flux at the ice/bed interface to determine water sheet thickness and then use the modeled groundwater aquifer transmissivity as a point of comparison to the water sheet's transmissivity. We chose Dome C (see Fig. 3) for the model study area as it has been examined extensively for various reasons, including hydrological studies (e.g. Forieri et al., 2004; Tikku et al., 2005; Parrenin et al., 2007; Carter et al., 2009b). Dome C is also located in an area of high "radar lake" density and paucity of "active lakes" (Wright et al., 2014), which was advantageous for hypothesis testing. A critical input for the numerical model was the availability of lower-error melt rates in the study area (Carter et al., 2009b). The vast majority of the area is estimated to be at pressure-melting temperature at the ice base so all the work we present here at the ice base and in the subsurface assumes that water is in a liquid state and that

115 thermodynamic modeling is not required (Siegert et al., 2007; Pattyn, 2010). The presence of subglacial lakes also validates this assumption. The numerics of the coupled model are purposefully simplistic and applicable to areas similar to Dome $\mathrm{C}$ (mainly the interiors of continental ice sheets). The key characteristics of our model's applicability are areas: much larger than that of mountain glacier terrains, having low ice surface slopes, and with low melt rates from very slow basal ice velocity. Dome $\mathrm{C}$ exhibits all of those characteristics and is an ideal location for the model development. We determined the flow line along which the model was developed (see Fig. 3) by a method used by Carter et al. (2009a).

As previously mentioned, our simplistic model was designed to understand how the water sheet thickness and a hypothetical groundwater system might interact and correlate to subglacial lake stability under the East Antarctic Ice Sheet. As we were interested in a simple comparison between two hydrological systems, we chose the cross-sectional dimension of a subglacial flow path that follows a hydrologic potential (i.e. the path water takes at the base of the ice sheet). If the model were solved in a higher-dimensional framework, the aquifer would be three-dimensional and the water sheet would be in two dimensions (the plane between the ice and the bed). The groundwater portion of the model utilizes a steady, fully saturated Darcy flow approach. This is applicable as any available meltwater would drain into a dry subsurface before going into the 
The Cryosphere Discuss., doi:10.5194/tc-2016-141, 2016

Manuscript under review for journal The Cryosphere

Published: 15 July 2016

(c) Author(s) 2016. CC-BY 3.0 License.

water sheet until the porous media was fully saturated which should be the case since the ice at Dome C has probably existed

130 in a similar configuration to the present for tens of millions of years (e.g. Huybrechts, 1993; Siegert et al., 2005b; Young et al., 2011). Since we do not have actual data about the subsurface hydraulic system, we simply adjust various permeability assumptions covering a wide range of geologic possibilities for the area. We also leave the top boundary as a constant head boundary to simply produce groundwater fluxes as an applied forcing to the water sheet (we provide further description of this later).

The 2D governing equation for steady state, fully saturated groundwater flow is

$-\nabla \cdot\left(\frac{k}{\mu} \nabla P+\rho_{w} g \nabla z_{b}\right)=0$

where $P$ is the pore water pressure to be solved, $\nabla \cdot$ is the divergence (used here in two dimensions as $\partial / \partial x+\partial / \partial z$ ), $k$ is the matrix permeability, $\mu$ is the viscosity of the water, $z_{b}$ is the bed elevation, and $\nabla$ is the gradient (also used here in two dimensions as $\partial / \partial x \boldsymbol{i}+\partial / \partial z \boldsymbol{k}$, where $\boldsymbol{i}$ and $\boldsymbol{k}$ are unit vectors). Note that the term inside the parentheses is the $2 \mathrm{D}$ groundwater volume flux (i.e. $q=-\mathrm{k} \nabla P / \mu+\rho_{w} g \nabla z_{b}$, which is similar to the previous form used for 1D flow where $q=-\mathrm{k} \nabla P(\mu)$ at any given location in the model domain. The matrix permeability, $k$, is evaluated using an exponential

145 decay function (á la Athy, 1930; Sclater and Christie, 1980): $k=k_{0} e^{-A\left(z_{b}-z\right)}$. Here, $k_{0}$ is the permeability at the top of the groundwater aquifer (i.e. bed elevation) which is allowed to vary in the model through a wide hydrogeologic range, $A$ is a decay parameter, and $\mathrm{z}$ is the elevation so that $z_{b}-z$ is the depth in the aquifer from the bed. The bottom of the aquifer is set at 1,500 m below sea level arbitrarily to allow a depth that enables regional groundwater flow (Jiang et al., 2009) and is less than the geophysically estimated thickness of the sedimentary basin fill for this area ( 2-3 km; Frederick, 2015), which

150 we chose in order to keep our argument more conservative (i.e. keeping the aquifer thickness minimized for transmissivity calculation). We also note that, for depths past a few hundred meters, the depth of the aquifer bed does not really impact the value of the groundwater volume flux at the ice/bed interface. The value of the decay exponent $(A)$ is $5 \times 10^{-3} \mathrm{~m}^{-1}$ as used in Jiang et al. (2009) in order to allow for a balance between regional and local groundwater flow systems; we also use this value as it is a more aggressive decay constant which allows us to make our argument more conservative. As our sole model

155 parameterization, we vary the sediment surface permeability of the bed, $k_{0}$, from a high value of $10^{-10} \mathrm{~m}^{2}$ (referred to subsequently as high $k_{0}$ ) to $10^{-18} \mathrm{~m}^{2}$ (low $k_{0}$ ) with a medium value of $10^{-14} \mathrm{~m}^{2}$ (med $k_{0}$ ) in order to test a wide range of geologic possibilities for Dome C (see Fig. S3 for a graphical view) and utilize groundwater flux as a sort of forcing function to the water sheet system above. Subglacial lakes were modeled as extensions of the groundwater domain by assigning the subglacial lakes an isotropic, homogeneous value of $k_{0}$ to obtain physically reasonable values of groundwater volume flux

160 along the lake bottom boundaries. The top and left boundaries are constant head boundaries (sits atop the lakes where they 
The Cryosphere Discuss., doi:10.5194/tc-2016-141, 2016

Manuscript under review for journal The Cryosphere

Published: 15 July 2016

(c) Author(s) 2016. CC-BY 3.0 License.

are present) and the bottom and right are no flow boundaries (i.e. water does not flow to the right of A or through the bottom boundary; see Fig. 4).

The governing equation for the water sheet was modeled similar to that of an expandable fracture where the laminar

165 flow is directed between two parallel plates. The glaciological community (specifically, Weertman, 1966) adapted this equation to describe the flow of water at the interface of an ice sheet by solving for sheet thickness (akin to fracture aperture), $d$, instead of pore pressure. The resulting $1 \mathrm{D}$ governing equation of the water sheet is

$-\nabla_{x} \cdot\left(\frac{d^{3}}{12 \mu} \nabla_{x} P_{w s}\right)=\dot{b}+G$

where $d$ is the water sheet thickness to be solved for, $P_{w s}$ is the given water sheet pressure, $\nabla_{x} \cdot$ is the one-dimensional divergence (i.e. $d / d x), \mu$ is the viscosity of the water, $\nabla_{x}$ is the one-dimensional gradient (i.e. $d / d x$ ), $\dot{b}$ is the melt rate from the base of the ice (a given source term from another model's output; see Appendix B), and $G$ is another source term for the water sheet that equals the modeled groundwater volume flux normal to the ice/bed interface $(G=q \cdot \boldsymbol{n})$, which is along the constant head boundary of the $2 \mathrm{D}$ groundwater model domain. Note that it is through the source term $G$ that we couple the output of the groundwater volume flux to the water sheet system. Plots of $G$ and $\dot{b}$ are shown in Fig. S4. The water sheet pressure is equal to the overlying ice sheet pressure, which is a fair assumption for this setting (Le Brocq et al., 2009). Therefore, the given water sheet pressure is calculated as $P_{w s}=\rho_{i} g(s-i)+\rho_{w} g\left(i-z_{b}\right)+\rho_{w} g z_{b}$, where $\rho_{i}$ is the density of ice, $\rho_{w}$ is the water density, $g$ is the acceleration due to gravity, $s$ is the elevation of the ice sheet surface, $i$ is the elevation

180 of the base of the ice, and $z_{b}$ is the elevation of the bed. The term in the middle allows for the pressure contribution of subglacial lakes such that where subglacial lakes exist $i \neq z_{b}$ otherwise $i=z_{b}$. The pressure for the constant head boundary in Eq. (1) uses this same formulation with the exception of the term accounting for the lake as that boundary lies above the lakes. The segments of the water sheet underlying the subglacial lakes are set to zero as to only model around them and set a required boundary condition. The value of the water viscosity $(\mu)$ is $8.94 \times 10^{-4} \mathrm{~Pa}$ s and the ice $\left(\rho_{i}\right)$ and water $\left(\rho_{w}\right)$ densities

185 are 920 and $1,000 \mathrm{~kg} \mathrm{~m}^{-3}$, respectively. More specifics about the model and its implementation into COMSOL Multiphysics (COMSOL, Inc.), an automated partial differential equations solver utilizing the finite element method, can be found in Appendix B.

\section{$4 \quad$ Results}

The modeled results consist primarily of the water sheet thickness and the subsurface pore pressure (or hydraulic

190 head) that are used to calculate water flux in both the aquifer and water sheet. Transmissivities can also be calculated using these results. The modeled water sheet thicknesses and resulting groundwater and water sheet transmissivities are plotted in 
The Cryosphere Discuss., doi:10.5194/tc-2016-141, 2016

Manuscript under review for journal The Cryosphere

Published: 15 July 2016

(c) Author(s) 2016. CC-BY 3.0 License.

Fig. 5. The results of the groundwater simulation are shown in Fig. 6. There are four different model results based on the input parameterizations of groundwater flux in addition to the given melt rate (i.e. high $k_{0}$, med $k_{0}$, low $k_{0}$, and melt only). The modeled water sheet thicknesses (Fig. 5a and 6a) fall into two distinct groups with all but one 195 parameterization ( $h i g h k_{0}$ ) essentially plotting the same as the melt only result with minor deviations, if any. The parameterizations that follow the melt only profile start at zero where subglacial lakes exist and gradually grow to a maximum before the next lake and repeat this process a few times. The maximum sheet thickness of these is about 2.5 millimeters. The high $k_{0}$ results are much different than the others. They fluctuate much more steeply than the other results and reach larger thicknesses at their maximum $(\sim 4-4.5 \mathrm{~mm})$.

The calculated transmissivities of the modeled water sheet thicknesses compared to the groundwater systems can be seen in Fig. 5b. We calculated the transmissivities $(T)$ for the model results a few different ways. For the groundwater values, we calculated the mean hydraulic conductivity $(K)$ of the varied groundwater models by taking the average function value integral of the depth-dependent formulation for permeability, $k$ (see Sect. 3 - Numerical Modeling Methods for the depth-dependent function). For the saturated thickness, $b$, of the groundwater subdomain we used the depth of aquifer along the profile. The product of these two values gave the $100 \%$ transmissivity value. The $10 \%$ value simply takes $10 \%$ of the $100 \%$ transmissivity value for an added level of conservative estimation. The transmissivities for the modeled water sheet simply use the product of the average water velocity and the water sheet thickness. Our choice of the depth-averaged water velocity (see Appendix A for specific formulation) instead of hydraulic conductivity was to again allow for potentially

210 higher values of transmissivity to more conservatively compare to those of the groundwater system. The water sheet transmissivities for all parameterizations cover many orders of magnitude of transmissivity ( $\sim 5$ by grouping or $\sim 6$ total) and extend above and below the med $k_{0}$ groundwater values at both the full $(100 \%)$ and fractional $(10 \%)$ aquifer thickness values. Only the high $k_{0}$ sheet parameterization reaches the highest fractional aquifer thickness transmissivity. Overall, the range of groundwater transmissivities envelops those of the water sheet system.

The results from the 2D groundwater model domain are shown in Fig. 6b (and additionally in Fig. S5), which specifically depicts the high $k_{0}$ model case. This figure is representative of the other models as it plots the horizontal pressure gradient, streamlines, and the relative magnitude and direction vectors of the groundwater volume flux that do not change with model parameterization. While the dominant driving force in groundwater flow is the ice sheet surface slope, localized bedrock effects can exert change in flow magnitude and even small-scale reversal in flow direction. Places where the horizontal pressure gradient is positive (i.e. with the ice surface gradient; to the left) low to negative (i.e. against the ice surface gradient; to the right) correlate well to locations of increased water sheet depth in the high $k_{0}$ model case (see Fig. 6) while locations where the horizontal pressure gradient is strongly positive (or there are lakes) correlate to absences of a modeled water sheet. 
The Cryosphere Discuss., doi:10.5194/tc-2016-141, 2016

Manuscript under review for journal The Cryosphere

Published: 15 July 2016

(c) Author(s) 2016. CC-BY 3.0 License.

\section{Discussion}

The numerical modeling results suggest that the addition of a groundwater flow system to a water sheet model of subglacial hydrology is critical for hydrological modeling under the interiors of continental ice sheets where melt rates are low $\left(<10 \mathrm{~mm} \mathrm{yr}^{-1}\right)$. This result specifically applies to continental ice sheet interiors containing bedrock surfaces whose surface permeability is within roughly the upper half of the permeability spectrum $\left(>10^{14} \mathrm{~m}^{2}\left(\right.\right.$ med $\left.k_{0}\right)$; see Table 8.2 ,

230 Singhal and Gupta, 2010). This is supported by the similarity in output water sheet thickness for most of the model parameterizations where all are largely the same as the melt only run except for the highest surface permeability parameterization to the medium permeability level (high $k_{0}$ to med $k_{0}$; see Fig. 5). The deviation from the melt only thickness trend starts at the med $k_{0}$ parameterization, which occurs because the med $k_{0}$ groundwater volume fluxes are on par with the melt rate (see Fig. S4). According to our model results, places where the surface and bed slopes are in unison

235 are unfavorable for water sheet development, given the permeability is higher than the med $k_{0}$ parameterization (cf. Fig. 6a and $6 \mathrm{~b}$ ). This is logical as the localized zones of low or reversed groundwater flow (compared to the regional flow direction to the left) would cause the water sheet to thicken to accommodate the regional gradient of water flow at the ice/bed interface. We believe this to be significant as roughly half of the hydraulic materials (i.e. geology) possibly extant in the bed could have a dominant control over the development of the basal water sheet system.

The groundwater modeling results (Fig. 6 and S5) show that there are many groundwater flow cells (with nested cells within them as well) throughout the model domain along the hydraulic flow path. While the flow is essentially horizontal there is some deviation from horizontal (i.e. slightly toward the vertical) in some locations. From our limited twodimensional groundwater domain, we see that the continuous groundwater transport across the entire domain is not probable as the directional (i.e. sign) changes in horizontal pressure gradient act as divides for subsurface fluid flow. A prominent example of one of these divides is at about $115 \mathrm{~km}$ (see Fig. 6b); this essentially cuts the upstream lakes off from the downstream one. However, given that water flow along the flow paths of the water sheet system strictly follows the smoothed gradient of the ice sheet surface slope in this scenario, it could be argued that groundwater could connect subglacial lakes by a combination of subsurface and subglacial water flow. This may be how the system works in reality where more transmissive groundwater systems transport large amounts of water (relatively slowly) over time and discharge water into the water sheet (where pressure gradients dictate they exist) which then carry water back into downstream groundwater systems, thus forming a larger-scale subglacial water transport system. However, out-of-plane groundwater transport (i.e. a 3D subsurface domain) might also connect the subglacial lakes without direct need for the water sheet system. 
The Cryosphere Discuss., doi:10.5194/tc-2016-141, 2016

Manuscript under review for journal The Cryosphere

Published: 15 July 2016

(c) Author(s) 2016. CC-BY 3.0 License.

than the water sheets (Fig. 5b). Even when we reduce the amount of groundwater aquifer thickness by an order of magnitude, which would be analogous to decreasing the aquifer thickness to one-tenth its modeled thickness, roughly the same trend with half of the hydrogeologic spectrum being on par or dominating the water sheet transmissivity is observed. In fact, it is only through the greatest modulation of groundwater flux that the water sheet is able to obtain its greatest modeled thickness, and thus, transmissivity for this modeling scenario.

Our results also suggest that subglacial lake stability in lower melt areas could be due to groundwater, where it is 265 the dominant transfer mechanism. This would explain a paucity of ice surface topographic expressions of lake dynamics (via rapid filling and then expulsion). We believe that the proposed subglacial water systems in this work are likely scenarios accounting for the stability of the East Antarctic subglacial lakes ("radar lakes"). Finally, we note that the nature of basal radar reflection coefficients, which are heavily influenced by the presence of water at the bed, might have a great deal of influence from groundwater flux at the bed. We note this as the pattern of basal refection strength (Fig. 3) along the

270 flow path does not trend the same as the water sheet (i.e. smoothly increasing) under low groundwater forcing but might with the higher forcing (i.e. correlation between high $k_{0}$ water sheet thickness and radar return coefficient peaks). However, there are many more complexities that influence the radar return signals at the ice/bed interface and we acknowledge that this will need further rigorous testing to better understand. Future efforts should eventually extend this model to a threedimensional framework (i.e. 2D water sheet; 3D groundwater) that couples ice dynamics and heat transport for permafrost

275 development and melt-rate calculations. This methodology for a coupled water sheet and groundwater system in ice sheet interiors, in combination with recent advances in ice-penetrating radar (Schroeder et al., 2014), may eventually assist in the ability to characterize sub-ice hydraulic (possibly even geologic) properties with careful treatment.

\section{Conclusion}

Our numerical model presented here demonstrates a basic method for coupling water sheet transport to twodimensional groundwater model output forcing, which is our initial attempt to connect two segmented communities trying to solve very closely related problems (cf. Flowers, 2015; Person et al., 2012). Our current approach is especially well suited for ice sheets that are thick enough to support a pressure-melting temperature at their base with minimal basal ice velocities (i.e. low frictional melt component). For ice sheets that do not meet these criteria, other approaches such as groundwater/channel coupling (Boulton et al., 2007) may be more appropriate or the groundwater system may be negated altogether (e.g. Kyrke-Smith et al., 2014) if the flux magnitudes are small enough when compared to a very efficient basal water system. Our model, as a two-dimensional model, may suffer due to a lack in accommodation of three-dimensional effects and interpolation biases in the topography. It is also possible that large heterogeneities in the hydrogeologic properties of the subsurface could cause deviations from the model. One example of this is karstic limestone (high, heterogeneous conductivity), which has been proposed for the area (Forieri et al., 2004) and supports our hypothesis of a 
The Cryosphere Discuss., doi:10.5194/tc-2016-141, 2016

Manuscript under review for journal The Cryosphere

Published: 15 July 2016

(c) Author(s) 2016. CC-BY 3.0 License.

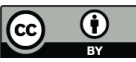

290 groundwater-dominant hydrologic system. However, our results do demonstrate that further advancement of subglacial groundwater transport mechanisms needs to take place (given the availability of greater subglacial geophysical and geologic information, another important task for current Antarctic research) and be incorporated into the subglacial hydrologic components of ice sheet models.

$7 \quad$ Figures

Theoretical Groundwater Volume Flux, q [mm $\mathrm{yr}^{-1}$ ]

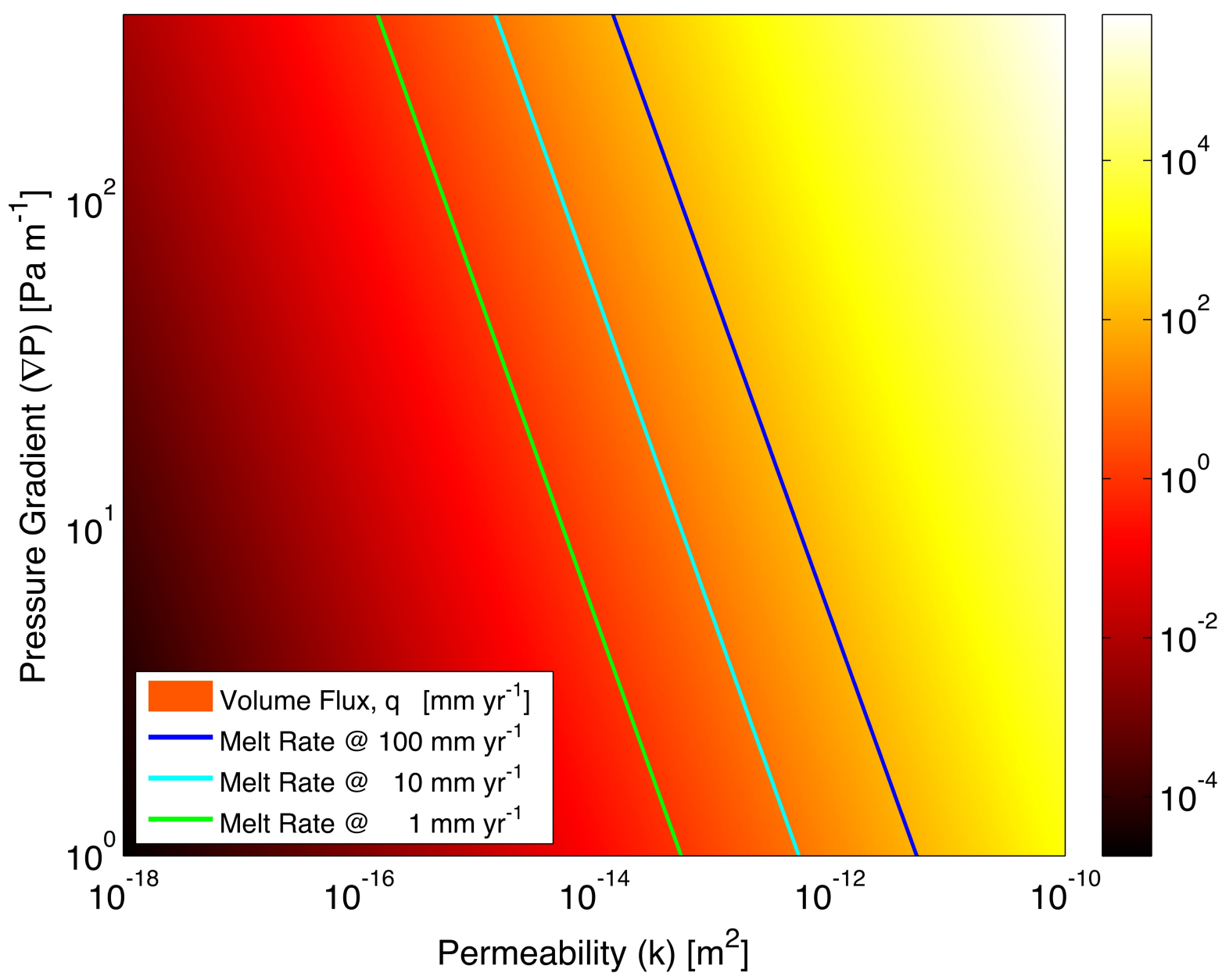


The Cryosphere Discuss., doi:10.5194/tc-2016-141, 2016

Manuscript under review for journal The Cryosphere

Published: 15 July 2016

(c) Author(s) 2016. CC-BY 3.0 License.

Figure 1. Plot of theoretical groundwater volume flux, $q$, over a wide range of permeabilities, $k$, (from "Very Low" (left) to "High" (right); see Table 8.2, Singhal and Gupta, 2010) and a typical range of pressure gradients $(\nabla P)$ for interior East Antarctica (see Figure S1 for the specific area). The range of pressure gradients extend from 1 to $\sim 380\left(10^{0}-10^{2.58}\right) \mathrm{Pa} \mathrm{m}^{-1}$. Basal ice sheet melt rates of 1,10 , and $100 \mathrm{~mm} \mathrm{yr}^{-1}$ have been plotted for comparison. The range of permeability may be converted to hydraulic conductivity, $K$, giving a range of $10^{-11}$ (left) to $10^{-3}$ (right) $\mathrm{m} \mathrm{s}^{-1}$.

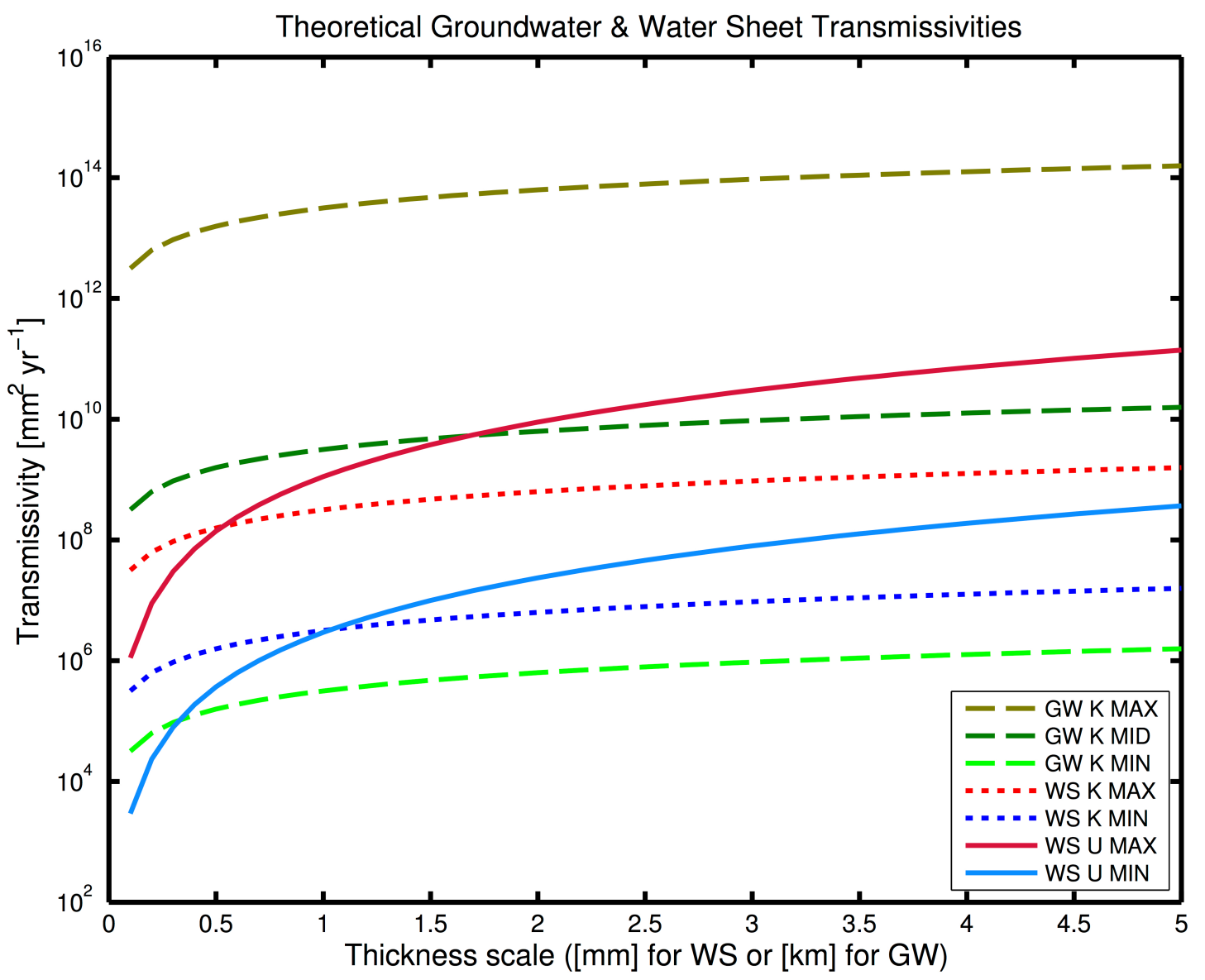

Figure 2. Plot of the theoretical groundwater (GW) and basal water sheet (WS) minimum (MIN) and maximum (MAX) transmissivities (ability of a horizontal layer to transmit water) given various hydraulic conductivities (K) or average water velocities (U). The transmissivity is dependent on the saturated thickness of a layer (either an aquifer or water sheet) and the hydraulic conductivity (the rate of the flow of water in a saturated layer; a measure of permeability). The transmissivity shown 
The Cryosphere Discuss., doi:10.5194/tc-2016-141, 2016

Manuscript under review for journal The Cryosphere

Published: 15 July 2016

(c) Author(s) 2016. CC-BY 3.0 License. line.

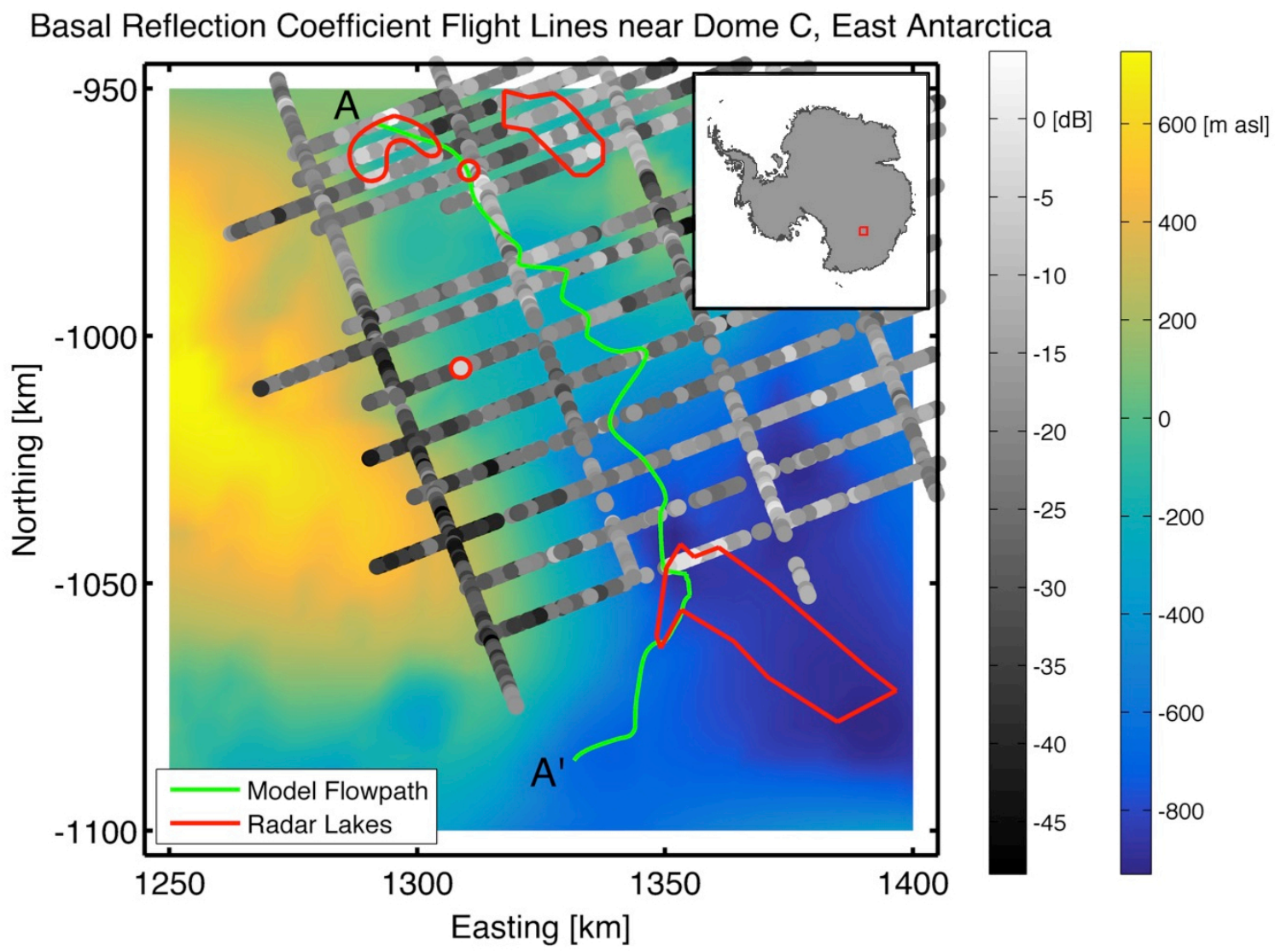

Figure 3. Location of the study area used in the model. The red box in the inset denotes the area shown in the interior of East Antarctica. Ice/bed interface elevation (Bedmap2; Fretwell et al., 2013) and radar basal reflection coefficient shown as flight line data points (in dB; Carter et al., 2009b) in the study area along with the model line and subglacial lake locations. In order from AA' (downstream) along the model line, the subglacial lakes plotted in red are Horseshoe, WLK 17, and Vincennes. Note that the lakes coincide with brighter (i.e. higher $\mathrm{dB}$ ) reflections. All elevations are in meters above current sea level. 
The Cryosphere Discuss., doi:10.5194/tc-2016-141, 2016

Manuscript under review for journal The Cryosphere

Published: 15 July 2016

(c) Author(s) 2016. CC-BY 3.0 License.

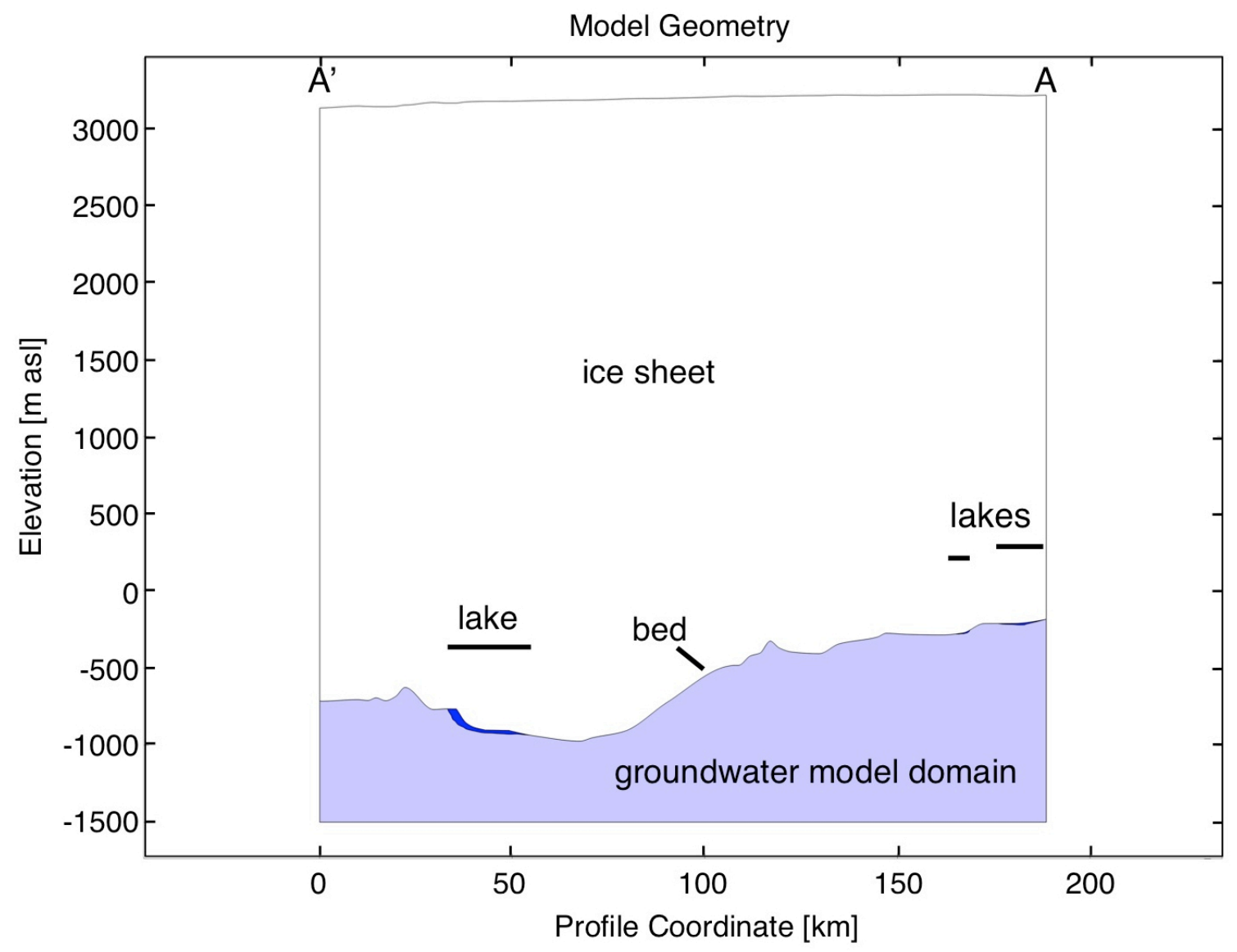

Figure 4. Model geometry used for the coupled 2D groundwater and 1D sub-ice water sheet model (curvilinear along the ice/bed interface boundary which is the top of the groundwater domain). The flow line location is shown in Fig. 3. Light blue denotes the groundwater subdomain and the dark blue denotes the subglacial lakes (marked by arrows). The white above represents the ice All elevations are in meters above current sea level. 
The Cryosphere Discuss., doi:10.5194/tc-2016-141, 2016

Manuscript under review for journal The Cryosphere

Published: 15 July 2016

(c) Author(s) 2016. CC-BY 3.0 License.

(a)
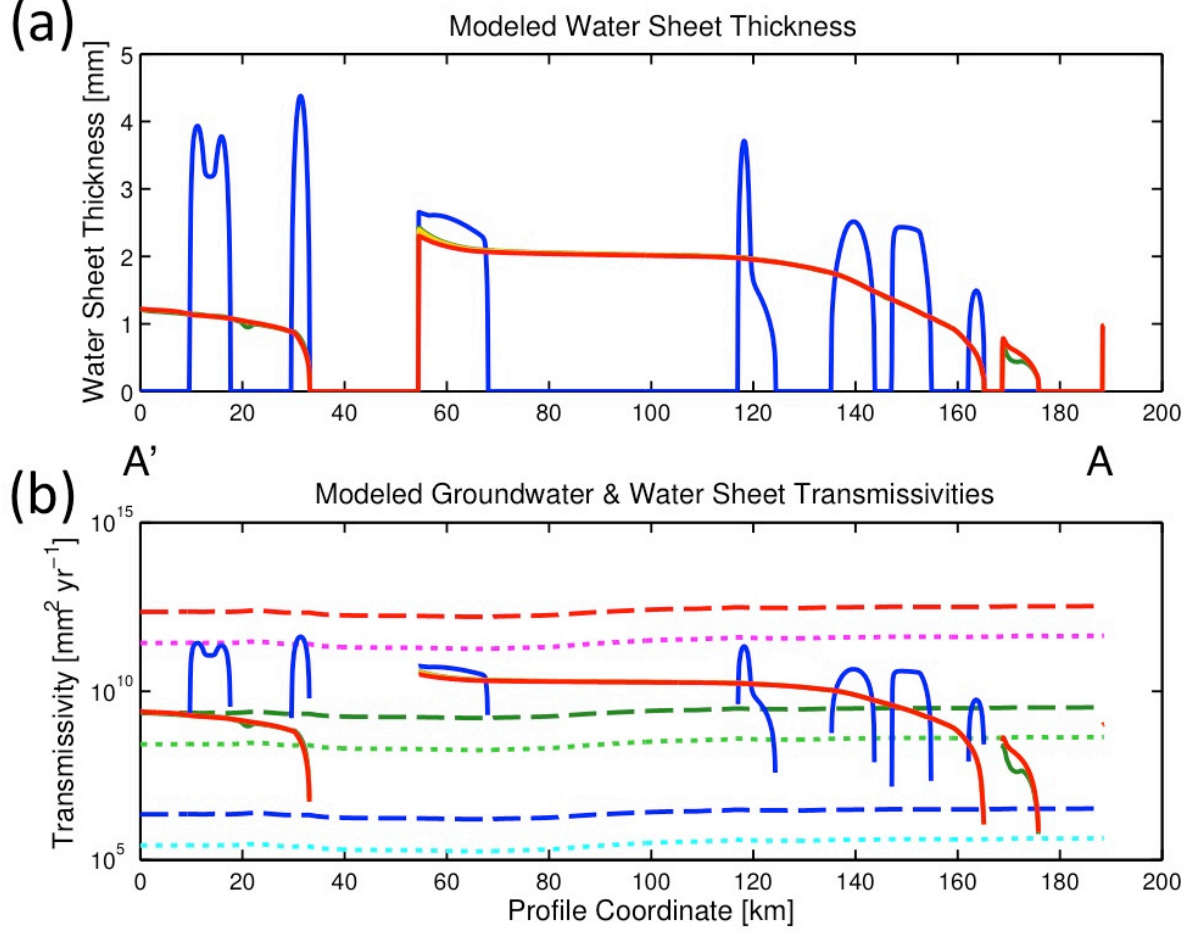

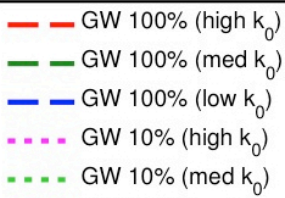

.... GW 10\% (med k

-... GW 10\% (low $\mathrm{k}_{\mathrm{o}}$

WS (med k $\mathrm{k}_{0}$ )

WS (low $k_{0}$ )

WS (melt only)

335 Figure 5. (a) Plot of the modeled water sheet thickness for varying source (G) parameterizations. Most of the parameterizations have similar results with the outlier being the model with the source parameterization utilizing the highest bed surface permeability coupled to the melt input (melt+gw $\left(h i g h k_{0}\right)$ ). Note that all results are at zero where subglacial lakes exist due to the Dirichlet boundary condition. The three subglacial lakes noted along the profile are at coordinates 33.2-54.4, 165.2-168.7, and 176.2-188.3 kilometers. (b) Plot of the calculated transmissivities of the modeled water sheet (WS) thicknesses and the

340 groundwater $(\mathbf{G W})$ aquifer thickness. The groundwater aquifer thickness is calculated at full thickness $(\mathbf{1 0 0 \%})$ as well as $10 \%$ in order to calculate low-end values for comparison. See Sect. 4 - Results for a detailed explanation of the hydraulic conductivities $(K)$ used in the transmissivity $(T)$ calculation for each plotted line. The location of the profile A-A' is shown in Fig. 3. 
The Cryosphere Discuss., doi:10.5194/tc-2016-141, 2016

Manuscript under review for journal The Cryosphere

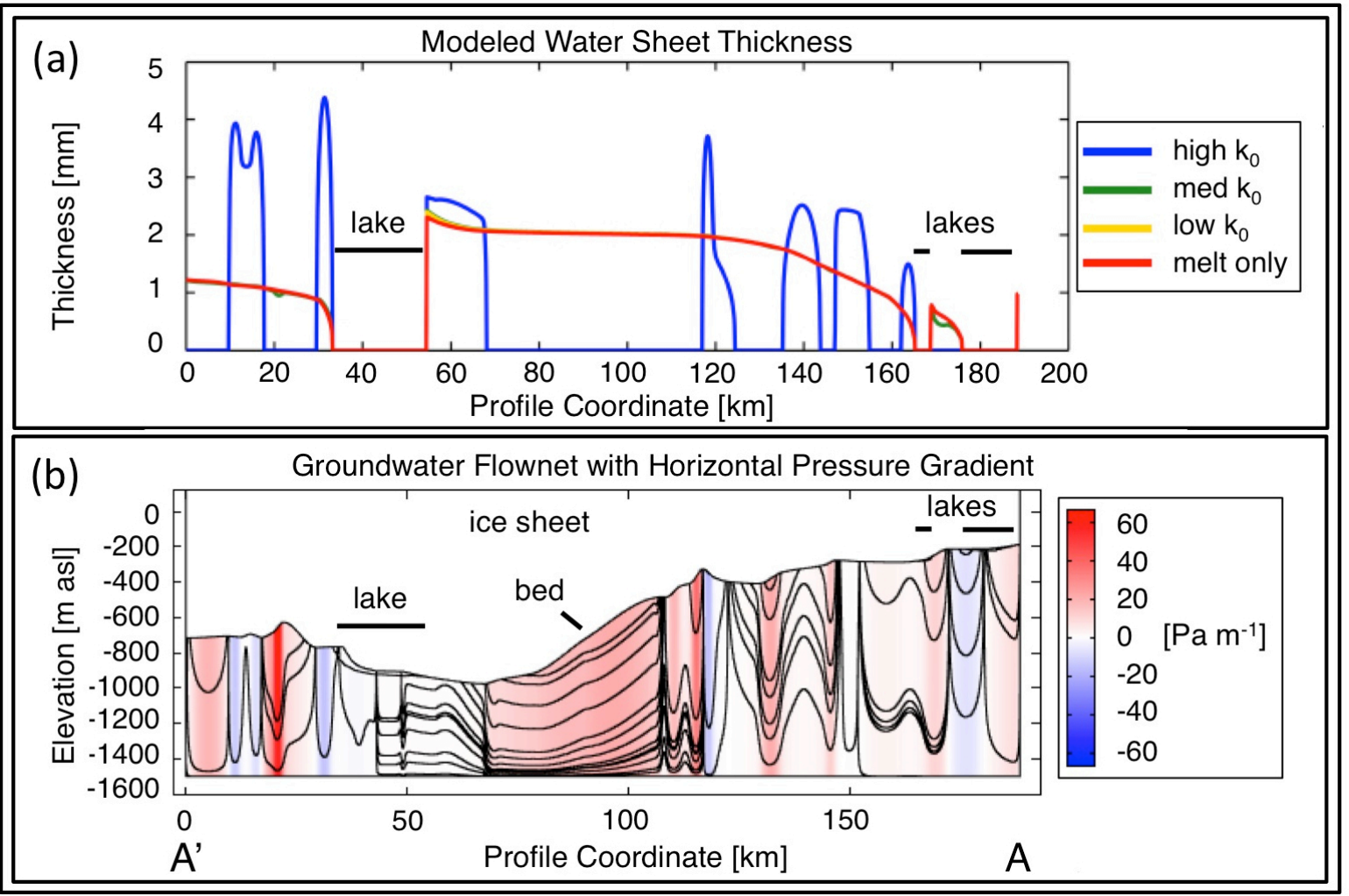

Figure 6. Plot of the modeled subsurface horizontal pressure gradient and the groundwater flownet streamlines (melt $+\mathrm{gw}$ (high $k_{0}$ ) model case). The streamlines shown represent potential pathways for groundwater and are not equal magnitudes but rather controlled by surface point selection. The three subglacial lakes along the profile are at coordinates 33.2-54.4, 165.2-168.7, and 176.2-188.3 kilometers. Negative pressure gradients (blue) cause water to flow to the right while positive pressure gradients

350 (red) cause flow to the left (i.e. with the downstream subglacial water flow). The location of the profile A-A' is shown in Fig. 3. Also note the high level of vertical exaggeration $(40 x)$ and that the horizontal flow vector is shown, as it is the dominant flow vector over the vertical (not shown).

\section{$8 \quad$ Appendices \\ 8.1 Appendix A}

Figure 1 shows the ranges of groundwater volume flux, $q$, for a very wide range of permeabilities $(k)$ and a range of water pressure gradients $(\nabla P)$ present in East Antarctica. The range of pressure gradients was selected using the area shown in Fig. S1, which yielded a range of 1 to $\sim 380\left(10^{0}-10^{2.58}\right) \mathrm{Pa}$ meter ${ }^{-1}$. The range of permeability we used was derived from Table 8.2 in Singhal and Gupta (2010); note that the "Very high" data were excluded in order to have a more conservative 
The Cryosphere Discuss., doi:10.5194/tc-2016-141, 2016

Manuscript under review for journal The Cryosphere

Published: 15 July 2016

(c) Author(s) 2016. CC-BY 3.0 License.

comparison. We calculated the groundwater transmissivities $(T)$ in Fig. 2 by using the maximum and minimum

360 permeabilities used in Fig. 1 and converted them to a hydraulic conductivity $(K)$ maximum and minimum of $10^{-3}$ and $10^{-11} \mathrm{~m}$ $\mathrm{s}^{-1}$, respectively. We also calculated a medium value using $10^{-7} \mathrm{~m} \mathrm{~second}^{-1}$. These hydraulic conductivities were multiplied by a saturated thickness $(b)$ to complete the transmissivity calculation (i.e. $T=K b$ ). To calculate the transmissivities of water sheets we chose two approaches. The first approach simply used published (Flowers and Clarke, 2002) maximum and minimum hydraulic conductivities of $10^{-2}$ and $10^{-4} \mathrm{~m} \mathrm{~s}^{-1}$, respectively. Another method we chose was to calculate the depth-

365 averaged velocity of the water sheet $\left(d^{2} \nabla P / 12 \mu\right.$; laminar flow between parallel plates as in Weertman (1966)) to use instead of the hydraulic conductivities from before. We calculated a maximum and minimum depth-averaged water velocity in the sheet by using the maximum and minimum pressure gradients used in the calculations for Fig. 1. This calculation provided us with a wider range of water sheet transmissivities in order to more conservatively compare the water sheet to groundwater transport.

\subsection{Appendix B}

We calculated the basal melt rates from a combined vertical strain inversion and temperature model that used agedated internal ice layers in radio-echo sounding data to calculate a vertical velocity and paleo-ice accumulation rate. The model then incorporated paleotemperatures from the Dome C Ice Core (Parrenin et al., 2007) and geothermal flux values

375 from the seismic tomography work of Shapiro and Ritzwoller (2004) to obtain a vertical temperature distribution for the ice and for this study a basal melt rate. A fuller description of this method appears in Carter et al. (2009b). We obtained flow paths by first plotting a contour map of the hydropotential and then tracing continuous local minima using the law of V's first practiced by Dupain-Triel (1791). At the intersections between this proto-flow path and the tracks of the available radio-echo sounding data we then found the nearest local minima in the hydropotential along the flow path. Our

380 hydropotential was based on radio-echo sounding ice surface elevations and ice thickness and also utilized Bedmap2 (Fretwell et al., 2013) where such radio-echo sounding data are sparse.

We used COMSOL Multiphysics (v.4.3b; COMSOL, Inc.) to create the coupled model presented in Sect. 3 Numerical Modeling Methods. The model uses Eq. (1) (as a preprogramed 2D module in COMSOL) with a modified 385 version of Eq. (2) for numerical stability reasons (as a custom 1D PDE into COMSOL). The coupling of the two models comes in as the groundwater volume flux $(G)$ normal to the bed surface (as an edge in 2D). We see this approach as novel as few efforts have incorporated groundwater with a subglacial hydrological model and none to our knowledge have additionally solved for the water sheet thickness $(d)$ simultaneously, which is critical for comparing where each system may dominate over the other.

390

Our 2D groundwater system was easily modeled via COMSOL as it is preconfigured to handle Darcian groundwater flow models in one to three dimensions. Modeling the lakes required treating them in the same domain as the 
The Cryosphere Discuss., doi:10.5194/tc-2016-141, 2016

Manuscript under review for journal The Cryosphere

Published: 15 July 2016

(c) Author(s) 2016. CC-BY 3.0 License.

groundwater system versus the approach used by others (Singha and Loheide, 2011) where lakes are given an unreasonably high permeability, which would skew the true groundwater flux values at the lake/bed interface. The choice of a fully

395 saturated model and constant head boundary along the top resulted from our desire to keep the pressure equal to the overburden pressure at the ice/bed interface and also be able to observe how the groundwater volume flux varies over that distance. If we had instead applied the melt rate as the boundary condition the flux would be equal to the melt rate (all positive into the aquifer), which would be unrealistic. While our choice is not fully realistic either, it does provide a better idea of how the two hydrological systems might interact. Another assumption was the neglect of a coupling back to the

400 pressure function in the groundwater head from the modeled water sheet. This is because the water sheet depth, $d$, is smaller than the elevation change in the topography by many orders of magnitude $(\sim 5)$. Adding in this update to the solver would have caused unnecessary computation with little-to-no effect on the groundwater solution.

The 1D water sheet model required substantially more effort to accomplish a realistic modeling result. In order to 405 provide a stable solution, a slight modification during the numerical implementation of Eq. (2) had to occur. Applying the divergence to the inner terms of the LHS of Eq. (2) yields the expanded form

$-\nabla_{x} \cdot\left(\frac{d^{3}}{12 \mu} \nabla_{x} P_{w s}\right)=-\frac{3 d^{2}}{12 \mu} \cdot \nabla_{x} P_{w s} \cdot \nabla_{x} d-\frac{d^{3}}{12 \mu} \cdot \nabla_{x}^{2} P_{w s}$

410 which is the first step to solve for the unknown $d$ instead of $P_{w s}$ which is known here. Taking the RHS of Eq. (2) and substituting into the LHS of Eq. (A1) gives

$\dot{b}+G=-\frac{3 d^{2}}{12 \mu} \cdot \nabla_{x} P_{w s} \cdot \nabla_{x} d-\frac{d^{3}}{12 \mu} \cdot \nabla_{x}^{2} P_{w s}$

415 which is the correct form of a steady nonlinear convection absorption equation in $d$. However, standard numerical methods for this equation are not stable. As with previous finite difference approaches to numerical stability (e.g. upwinding), we have also incorporated stability for finite elements known as artificial, or streamline, diffusion (Hauke and Hughes, 1994) by adding a very small diffusive term to the RHS giving

$420 \quad \dot{b}+G=-\frac{3 d^{2}}{12 \mu} \cdot \nabla_{x} P_{w s} \cdot \nabla_{x} d-\frac{d^{3}}{12 \mu} \cdot \nabla_{x}^{2} P_{w s}-\nabla_{x} \cdot\left(\frac{\left|\nabla_{x} P_{w s}\right|}{12 \mu} \cdot \frac{3 d^{2}}{2} \cdot \mathrm{h} \cdot \nabla_{x} d\right)$

where $\mathrm{h}$ is the element size and $\left|\nabla_{x} P_{w s}\right|$ is the absolute first pressure derivative with respect to $x$. Rearranging and simplifying Eq. (A3) yielded the more compact form of 
The Cryosphere Discuss., doi:10.5194/tc-2016-141, 2016

Manuscript under review for journal The Cryosphere

Published: 15 July 2016

(c) Author(s) 2016. CC-BY 3.0 License.

$425 \dot{b}+G=-\nabla_{x} \cdot\left(\frac{\left|\nabla_{x} P_{w s}\right| d^{2} h}{8 \mu} \nabla_{x} d\right)-\frac{3 d^{2} \nabla_{x} P_{w s}}{12 \mu} \cdot \nabla_{x} d-\frac{d^{2} \nabla_{x}{ }^{2} P_{w s}}{12 \mu} d$

which is in the more familiar form of a steady convection diffusion equation with an absorption term and source,

$f=-\nabla_{x} \cdot\left(c \nabla_{x} u\right)-\beta \cdot \nabla_{x} u+a u$

430

where $f$ is the source, $u$ is the dependent variable, and the rest are coefficients. The diffusive term is characterized by the coefficient $\mathrm{c}$, the convective component is characterized by the $\beta$ coefficient, and the absorptive term is characterized by the coefficient $a$. Note that these coefficients depend on the unknown $u$ (i.e. $d$ ), and therefore Eq. (A5) is a nonlinear convection diffusion equation. This form is in a format easily solved with COMSOL (as it is preprogrammed to handle this

435 form for both linear and nonlinear equations) given one final step. The last step in solving Eq. (1) and (A4) (originally Eq. (2)) simultaneously is to provide a stable input pressure function into Eq. (A4). The key to this is similar to other subglacial water modeling efforts (Le Brocq et al., 2006) where the pressure function must have its local minima removed. This step was done by hand in a spreadsheet with a graphic that depicted instantaneous changes made to the profile. The "filled" function also required smoothing to provide continuous derivatives in the pressure function. Figure S2 provides a comparison of this workflow's output in a graphical format.

The model specifics varied according to the specific physics solved in the model domain. The two-dimensional part of the domain (i.e. groundwater physics) contained 93,331 triangular finite elements and the one-dimensional part (i.e. water sheet physics) contained 3,815 edge elements yielding a total for the coupled model at 97,146 elements. The element size for the bulk of the entire model domain is $100 \mathrm{~m}$ with the groundwater subdomain having an element size range of 17-132 $\mathrm{m}$ and the water sheet subdomain having edge element sizes ranging 2-101 meters. When run separately on a modern laptop (c. 2010), COMSOL calculates the solution to solely the groundwater equation in $\sim 12 \mathrm{~s}$ and the water sheet alone in $\sim 16 \mathrm{~s}$ but when coupled, solution times range from $\sim 1$ minute to over 20 minutes depending on the parameterization of $k_{0}$.

\section{9}

\section{Acknowledgements}

Supplementary figures can be found at the online version of this article. We thank L. Wang, K. Befus, M. Hesse, and B. Cardenas for their assistance with Comsol Multiphysics. For assistance with MATLAB for data analysis, we thank

C. Greene. We also thank G. Muldoon, K. Soderlund, and The Cryosphere Discussions online community reviewers for their constructive feedback. Funding was provided by the G. Unger Vetlesen Foundation, OPP 99-11617 and NNX08AN68G to support this work. This is UTIG contribution \#2960. 
The Cryosphere Discuss., doi:10.5194/tc-2016-141, 2016

Manuscript under review for journal The Cryosphere

Published: 15 July 2016

(c) Author(s) 2016. CC-BY 3.0 License.

Alley, R. B.: Water-pressure coupling of sliding and bed deformation, I, Water system, J. Glaciol., 35, 108-118, 1989.

460 Anandakrishnan, S. and Alley, R. B.: Stagnation of Ice Stream C, West Antarctica by water piracy, Geophys. Res. Lett., 24, $265-268,1997$.

Athy, L. F.: Density, porosity, and compaction of sedimentary rocks, AAPG Bull., 14, 1-23, 1930.

465 Boulton, G. S., and Jones, A. S.: Stability of temperate ice sheets resting on beds of deformable sediment, J. Glaciol., 24, 2943, 1979.

Boulton, G. S., Caban, P. E., and Van Gijssel, K.: Groundwater flow beneath ice sheets: part 1-Large scale patterns, Quat. Sci. Rev., 14, 545-562, 1995.

Boulton, G. S., Lunn, R., Vidstrand, P., and Zatsepin, S.: Subglacial drainage by groundwater-channel coupling, and the origin of esker systems: Part 2 - theory and simulation of a modern system, Quat. Sci. Rev., 26, 1091-1105, 2007.

Carter, S. P., Blankenship, D. D., Peters, M. E., Young, D. A., Holt, J. W., and Morse, D. L.: Radar-based subglacial lake classification in Antarctica, Geochem. Geophys. Geosyst., 8, Q03016, doi:10.1029/2006GC001408, 2007.

Carter, S. P., Blankenship, D. D., Young, D. A., Peters, M. E., Holt, J. W., and Siegert, M. J.: Dynamic distributed drainage implied by the flow evolution of the 1996-1998 Adventure Trench subglacial lake discharge, Earth Planet. Sci. Lett., 283(14), 24-37, doi:10.1016/j.eps1.2009.03.019, 2009a.

Carter, S. P., Blankenship, D. D., Young, D. A., and Holt, J. W.: Using radar-sounding data to identify the distribution and sources of subglacial water: Application to Dome C, East Antarctica, J. Glaciol., 55(194), 1025-1040, doi:10.3189/002214309790794931, 2009b.

485 Carter, S. P., H. A. Fricker, D. D. Blankenship, J. V. Johnson, W. H. Lipscomb, S. F. Price, and D. A. Young (2011), Modeling 5 years of subglacial lake activity in the MacAyeal Ice Stream (Antarctica) catchment through assimilation of ICESat laser altimetry, J. Glaciol., 57(206), 1098-1112. 
The Cryosphere Discuss., doi:10.5194/tc-2016-141, 2016

Manuscript under review for journal The Cryosphere

Published: 15 July 2016

(c) Author(s) 2016. CC-BY 3.0 License.

Carter, S. P., Fricker, H. A., and Siegfried, M. R.: Active lakes in Antarctica survive on a sedimentary substrate - Part 1:

Theory, The Cryosphere Discuss., 9, 2053-2099, doi:10.5194/tcd-9-2053-2015, 2015.

Christianson, K., Jacobel, R. W., Horgan, H. J., Anandakrishnan, S., and Alley, R. B.: Subglacial Lake Whillans-Icepenetrating radar and GPS observations of a shallow active reservoir beneath a West Antarctic ice stream, Earth Planet. Sci. Lett., 331-332, 237-245, doi:10.1016/j.eps1.2012.03.013, 2012.

Creyts, T. T., and Schoof, C. G.: Drainage through subglacial water sheets, J. Geophys. Res., 114, F04008, doi:10.1029/2008JF001215, 2009.

Dupain-Triel, J. L.: La France considérée dans les différentes hauteurs de ses plaines: ouvrage spécialement destiné al'instruction de la jeunesse, (BN, Cartes et Plans, map No. Ge. D.15126) Hérault, Paris, 1791.

Flowers, G. E., and Clarke, G. K. C.: A multicomponent coupled model of glacier hydrology: 1. Theory and synthetic examples, J. Geophys. Res., 107(B11), 2287, doi:10.1029/2001JB001122, 2002.

Flowers, G. E.: Modelling water flow under glaciers and ice sheets, Proc. A, 471, 2015.

Forieri, A., Zuccoli, L., Bini, A., Zirizzotti, A., Remy, F., and Tabacco, I. E.: New bedrock map of Dome C, Antarctica, and morphostructural interpretation of the area, Ann. Glaciol., 39(1), 321-325, 2004.

510 Frederick, B. C.: Submarine Sedimentary Basin Analyses for the Aurora and Wilkes Subglacial Basins and the Sabrina Coast Continental Shelf, East Antarctica, Ph.D. dissertation, Univ. of Texas, Austin, Texas, USA, 2015.

Fretwell, P., Pritchard, H. D., Vaughan, D. G., Bamber, J. L., Barrand, N. E., Bell, R., Bianchi, C., Bingham, R. G., Blankenship, D. D., Casassa, G., Catania, G., Callens, D., Conway, H., Cook, A. J., Corr, H. F. J., Damaske, D., Damm, V.,

515 Ferraccioli, F., Forsberg, R., Fujita, S., Gim, Y., Gogineni, P., Griggs, J. A., Hindmarsh, R. C. A., Holmlund, P., Holt, J. W., Jacobel, R. W., Jenkins, A., Jokat, W., Jordan, T., King, E. C., Kohler, J., Krabill, W., Riger-Kusk, M., Langley, K. A., Leitchenkov, G., Leuschen, C., Luyendyk, B. P., Matsuoka, K., Mouginot, J., Nitsche, F. O., Nogi, Y., Nost, O. A., Popov, S. V., Rignot, E., Rippin, D. M., Rivera, A., Roberts, J., Ross, N., Siegert, M. J., Smith, A. M., Steinhage, D., Studinger, M., Sun, B., Tinto, B. K., Welch, B. C., Wilson, D., Young, D. A., Xiangbin, C., and Zirizzotti, A.: Bedmap2: improved ice bed, surface and thickness datasets for Antarctica, The Cryosphere, 7, 375-393, doi:10.5194/tc-7-375- 2013, 2013. 
The Cryosphere Discuss., doi:10.5194/tc-2016-141, 2016

Manuscript under review for journal The Cryosphere

Published: 15 July 2016

(c) Author(s) 2016. CC-BY 3.0 License.

Fricker, H. A., Scambos, T., Bindschadler, R., and Padman, L.: An active subglacial water system in West Antarctica mapped from space, Science, 315(5818), 1544-1548, doi:10.1126/science.1136897, 2007.

525 Fricker, H.A.: Glaciology: water slide, Nature Geosci., 1(12), 809-816, 2008.

Fricker, H. A. and Scambos, T.: Connected subglacial lake activity on lower Mercer and Whillans Ice Streams, West Antarctica, 2003-2008, J. Glaciol., 55, 303-315, 2009.

530 Fricker, H. A., Scambos, T., Carter, S., Davis, C., Haran, T., and Joughin, I.: Synthesizing multiple remote-sensing techniques for subglacial hydrologic mapping: application to a lake system beneath MacAyeal Ice Stream, West Antarctica, J. Glaciol., 56, 187-199, 2010.

Hauke, G., and Hughes, T. J. R.: A unified approach to compressible and incompressible flows, Computer Methods in 535 Applied Mechanics and Engineering, 113(3), 389-395, 1994.

Huybrechts, P.: Glaciological modelling of the late cenozoic East Antarctic Ice Sheet: Stability or dynamism?, Geogr. Ann., 75A(4), 221-238, 1993.

540 Jiang, X.-W., Wan, L., Wang, X.-S., Ge, S., and Liu, J.: Effect of exponential decay in hydraulic conductivity with depth on regional groundwater flow, Geophys. Res. Lett., 36, L24402, doi:10.1029/2009GL041251, 2009.

Johnson, J.: A basal water model for ice sheets, Ph.D. dissertation, Univ. of Maine, Orono, Maine, USA, 2002.

545 Johnson, J. and Fastook, J. L.: Northern Hemisphere glaciation and its sensitivity to basal melt water, Quatern. Int., 95-96, 65-74, doi:10.1016/S1040-6182(02)00028-9, 2002.

Kyrke-Smith, T. M., Katz, R. F., and Fowler, A. C.: Subglacial hydrology and the formation of ice streams, Proc. Phys. Soc. London, Sect. A, 470, 20,130,494, doi:10.1098/rspa.2013.0494, 2014.

550

Le Brocq, A. M., Payne, A. J., and Siegert, M. J.: West Antarctic balance calculations: Impact of flux-routing algorithm, smoothing and topography, Comput. Geosci., 32(10), 1780-1795, 2006.

Le Brocq, A. M., Payne, A., Siegert, M., and Alley, R.: A subglacial water-flow model for West Antarctica, J. Glaciol., 555 55(193), 879-888, 2009. 
The Cryosphere Discuss., doi:10.5194/tc-2016-141, 2016

Manuscript under review for journal The Cryosphere

Published: 15 July 2016

(c) Author(s) 2016. CC-BY 3.0 License.

Lemieux, J.-M., Sudicky, E., Peltier, W., and Tarasov, L.: Dynamics of groundwater recharge and seepage over the Canadian landscape during the Wisconsinian glaciation, J. Geophys. Res., 113, F01011, doi:10.1029/2007JF000838, 2008.

560 Parrenin, F., Barnola, J.-M., Beer, J., Blunier, T., Castellano, E., Chappellaz, J., Dreyfus, G., Fischer, H., Fujita, S., Jouzel, J., Kawamura, K., Lemieux-Dudon, B., Loulergue, L., Masson-Delmotte, V., Narcisi, B., Petit, J.-R., Raisbeck, G., Raynaud, D., Ruth, U., Schwander, J., Severi, M., Spahni, R., Steffensen, J. P., Svensson, A., Udisti, R., Waelbroeck, C., and Wolff, E.: The EDC3 chronology for the EPICA Dome C ice core, Clim. Past, 3, 485-497, doi:10.5194/cp-3-485-2007, 2007.

565 Pattyn, F.: Antarctic subglacial conditions inferred from a hybrid ice sheet/ice stream model, Earth Planet. Sci. Lett., 295(34), 451-461, doi:10.1016/j.eps1.2010.04.025, 2010.

Person, M., McIntosh, J., Bense, V., and Remenda, V.: Pleistocene hydrology of North America: The role of ice sheets in reorganizing groundwater systems, Rev. Geophys., 45, RG3007, doi:10.1029/2006RG000206, 2007.

Person, M., Bense, V., Cohen, D., and Banerjee, A.: Models of ice-sheet hydrogeologic interactions: A review, Geofluids, $12,58-78,2012$.

Peters, M. E., Blankenship, D. D., Carter, S. P., Kempf, S. D., Young, D. A., and Holt, J. W.: Along-track focusing of 575 airborne radar sounding data from West Antarctica for improving basal reflection analysis and layer detection, IEEE Trans. Geosci. Remote Sens., 45(9), 2725-2736, doi:10.1109/TGRS.2007.897416, 2007.

Piotrowski, J.: Subglacial hydrology in north-western Germany during the last glaciations: Groundwater flow, tunnel valleys and hydrological cycles, Quat. Sci. Rev., 16, 169-185, 1997.

Schroeder, D. M., Blankenship, D. D., Young, D. A., Witus, A. E., and Anderson, J. B.: Airborne radar sounding evidence for deformable sediments and outcropping bedrock beneath Thwaites Glacier, West Antarctica, Geophys. Res. Lett., 41, 7200-7208, doi:10.1002/2014GL061645, 2014.

585 Sclater, J. G., and Christie, P.: Continental stretching: An explanation of the post-mid-cretaceous subsidence of the central North Sea basin, J. Geophys. Res. Solid Earth, 85(B7), 3711-3739, 1980.

Shapiro, N. M., and Ritzwoller, M. H.: Inferring surface heat flux distributions guided by a global seismic model: Particular application to Antarctica, Earth Planet. Sci. Lett., 223, 213-224, 2004. 
The Cryosphere Discuss., doi:10.5194/tc-2016-141, 2016

Manuscript under review for journal The Cryosphere

Published: 15 July 2016

(c) Author(s) 2016. CC-BY 3.0 License.

Shreve, R. L.: Movement of water in glaciers, J. Glaciol., 11(62), 205-214, 1972.

Siegert, M. J., Carter, S., Tabacco, I., Popov, S., and Blankenship, D. D.: A revised inventory of Antarctic subglacial lakes, Antarct. Sci., 17, 453-460, doi:10.1017/s0954102005002889, 2005a.

Siegert, M. J., Taylor, J. P., and Antony, J.: Spectral roughness of subglacial topography and implications for former icesheet dynamics in East Antarctica, Global Planet. Change, 45, 249-263, 2005 b.

Siegert, M. J., Le Brocq, A. M., and Payne, A. J.: Hydrological connections between Antarctic subglacial lakes and the flow of water beneath the East Antarctic Ice Sheet, in Glacial Sedimentary Processes and Products, Spec. Publ., vol 39, edited by M. J. Hambrey et al., pp. 3-10, Int. Assoc. of Sedimentol., Malden, Mass, 2007.

Siegert, M. J., Ross, N., Corr, H., Smith, B., Jordan, T., Bingham, R. G., Ferraccioli, F., Rippin, D. M., and Le Brocq, A.: Boundary conditions of an active West Antarctic subglacial lake: implications for storage of water beneath the ice sheet, The

Cryosphere, 8, 15-24, doi:10.5194/tc-8-15-2014, 2014.

Singha, K., and Loheide II, S. P.: Linking physical and numerical modelling in hydrogeology using sand tank experiments and COMSOL Multiphysics, Int. J. Sci. Educ., 33(4), 547-571, 2011.

610 Singhal, B. B. S., and Gupta, R. P.: Applied Hydrogeology of Fractured Rocks, Kluwer Acad., Dordrecht, The Netherlands, 2010.

Smith, B. E., Fricker, H. A., Joughin, I. R., and Tulaczyk, S.: An inventory of active subglacial lakes in Antarctica detected by ICESat (2003-2008), J. Glaciol., 55, 573-595, doi:10.3189/002214309789470879, 2009.

615

Stauffer, P. H.: Flux flummoxed: A proposal for consistent usage, Ground water, 44(2), 125-128, 2006.

Stearns, L., Smith, B., and Hamilton, G.: Increased flow speed on a large East Antarctic outlet glacier caused by subglacial floods, Nat. Geosci., 1(12), 827-831, doi:10.1038/ngeo356, 2008.

620

Tikku, A. A., Bell, R. E., Studinger, M., Clarke, G. K. C., Tabacco, I., Ferraccioli, F.: Influx of meltwater to subglacial Lake Concordia, East Antarctica, J. Glaciol., 51(172), 96-104, 2005. 
The Cryosphere Discuss., doi:10.5194/tc-2016-141, 2016

Manuscript under review for journal The Cryosphere

Published: 15 July 2016

(c) Author(s) 2016. CC-BY 3.0 License.

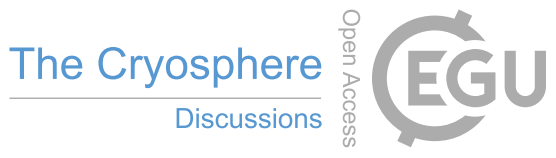

(c) (i)

Weertman, J.: Effect of a basal water layer on the dimensions of ice sheets, J. Glaciol., 6(44), 191-207, 1966.

625

Wingham, D. J., Siegert, M. J., Shepherd, A., and Muir, A. S.: Rapid discharge connects Antarctic subglacial lakes, Nature, 440, 1033-1036, doi:10.1038/nature04660, 2006.

Wright, A., and Siegert, M.: A fourth inventory of Antarctic subglacial lakes Antarctic, Science, 24(06), 659-664, 630 doi:10.1017/S095410201200048X, 2012.

Wright, A. P., Young, D. A., Roberts, J. L., Schroeder, D. M., Bamber, J. L., Dowdeswell, J. A., Young, N. W., Le Brocq, A. M., Warner, R. C., Payne, A. J. and Blankenship, D. D.: Evidence of a hydrological connection between the ice divide and ice sheet margin in the Aurora Subglacial Basin, East Antarctica, J. Geophys. Res., 117, F01033, doi:10.1029/2011JF002066, 2012.

Wright, A. P., Young, D. A., Bamber, J. L., Dowdeswell, J. A., Payne, A. J., Blankenship, D. D. and Siegert, M. J.: Subglacial hydrological connectivity within the Byrd Glacier catchment, East Antarctica, J. Glaciol., 60(220), 345-352, doi:10.3189/2014JoG13J014, 2014.

640

Young, D. A., Wright, A. P., Roberts, J. L., Warner, R. C., Young, N. W., Greenbaum, J. S., Schroeder, D. M., Holt, J. W., Sugden, D. E., Blankenship, D. D. and van Ommen, T. D.: A dynamic early East Antarctic Ice Sheet suggested by icecovered fjord landscapes, Nature, 474(7349), 72-75, 2011. 